Unresolved issues and new challenges in teaching English to young learners: the case of South Korea

\title{
Sue Garton
}

School of Languages and Social Sciences, Aston University, Birmingham, UK

Sue Garton, School of Language and Social Sciences, Aston University, Birmingham B47ET, UK.s.garton@aston.ac.uk. 


\title{
Unresolved issues and new challenges in teaching English to young learners: the case of South Korea
}

\author{
The introduction of languages, especially English, into the primary curriculum \\ around the world has been one of the major language-in-education policy \\ developments in recent years. In countries where English has been compulsory for \\ a number of years, the question arises as to what extent the numerous and well- \\ documented challenges faced by the initial implementation of early language \\ learning policies have been overcome and whether new challenges have arisen as \\ policies have become consolidated.
}

This article therefore focuses on South Korea, where English has been compulsory in primary school since 1997. The issues raised by the introduction of English into the primary curriculum are reviewed and the current situation in South Korea is investigated. The results of a mixed methods study using survey data from 125 Korean primary school teachers, together with data from a small-scale case study of one teacher are presented. The study shows that, while some of the initial problems caused by the introduction of early language learning appear to have been addressed, other challenges persist. Moreover, the data reveal the emergence of a number of new challenges faced by primary school teachers of English as they seek to implement government policy.

\section{Key words}

Language-in-education, early language learning, Teaching English to Young Learners (TEYL), teacher education

\section{Introduction}

A considerable amount of research has been carried out into teaching English to young learners in Asia from the point of view of language policy and planning both at a regional level(see, for example, Baldauf, Kaplan, Kamwangamalu, \& Bryant, 2011; Ho, 2003; Ho \& Wong, 2003b; Nunan, 2003)and in specific countries such as mainland China(G. Hu, 2005a; Y. Hu, 2007), Japan (Butler \& Iino, 2005), Hong Kong (Carless, 
1998), Malaysia (Ali, Hamid, \& Moni, 2011), South Korea (J. Lee, 2004), Taiwan (Chen, 2011),Thailand (Foley, 2005)and Vietnam(Nguyen, 2011) . Other studies have focused in particular on actual implementation, especially in terms the gap between policy and practice caused by the introduction of new methodologies such as communicative language teaching (see, example, Butler, 2005; Carless, 2004; G. Hu, 2005b; D.-M. Kang, 2008; Mitchell \& Lee, 2003; Prapaisit de Segovia \& Hardison, 2008).

In some countries, such as Vietnam, the introduction of English as a compulsory subject at primary level is relatively recent(Nguyen, 2011). However, in others, such as Taiwan or Thailand, such policies have now been in place for a decade or more. In countries where English has been compulsory for a number of years, the question arises as to what extent the numerous challenges to the initial implementation of primary language-in-education policies have been overcome and whether new challenges have arisen as policies have become consolidated.

The study reported in this article focuses on South Korea, where English was introduced into third grade in primary schools in 1997. The issues raised by the introduction of English into the primary curriculum are reviewed and the current situation in South Korea is investigated from the point of view of one particular group of stakeholders, primary school teachers of English. Using a mixed methods approach with survey data from 125 teachers, together with in-depth data from a case study of one teacher, key solutions to some initial problems are identified, together with the emergence of a number of new challenges.

\section{Language-in-Education Policy in South Korea}


The Ministry of Education, Science and Technology (MEST) in South Korea introduced English as a compulsory subject in Grade 3 in 1997. Lee (2009, pp. 95-96) identifies three key reasons underlying this decision:

(1) to create more equal opportunities for children to learn English;

(2) to improve teaching methods, which tend to be based on Grammar-Translation in secondary schools;

(3) to ensure the competitiveness of South Korea in the global economy. Compared to many countries, the Korean government took a strong centralised approach to English language education, with close control over curriculum and materials (Butler, 2005).H.D.Kang (2012) notes that the curriculum dictates both the words required for primary English and the number of words that can be used in a sentence.

In order to address the inevitable shortage of teachers created by the introduction of compulsory English at primary level, it was mainly regular class teachers who taught English, receiving a minimum of 120 hours in-service training in language and methodology (Butler, 2005). Over time, the number of specialist English teachers employed has increased (Butler, 2004; Mitchell \& Lee, 2003). In 2000, the new National Curriculum of primary English was introduced with three main aims (W. L. Lee, 2009, p. 96):

(1) To foreground spoken English in an attempt to counteract the use of grammartranslation, and rote learning and the examination focus in secondary schools.

(2) To make the curriculum more learner-centred with an emphasis on games, songs and chants. 
(3) To introduce "level-based teaching". With average class sizes of around 35 children, the government aimed to encourage the use of group work at different levels.

In 2001, the government went one step further and introduced a policy to teach English through English or TETE (D.-M. Kang, 2008; Nunan, 2003) and announced that there would be one class hour a week taught entirely in English in grades 3-6 (Butler, 2004).

In its Major Policies and Plans for 2010, MEST (2009) declared its intention to improve the provision of state education, in particular for English. Apart from the increase in the number of hours taught, improvement was to be achieved by expanding theTETE scheme to the national level by March 2010, with more intensive training offered to English teachers. Finally, the use of native speaker assistant teachers was to be strengthened through training and through increased recruitment on to the Teach and Learn in Korea scheme (TaLK) to rural schools in particular (MEST, 2009), although MEST did not specify whether these teachers would work in primary or secondary schools.

Together with a previous goal in the Major Policies and Plans for 2009 (MEST, 2008) to train 5000 English-speaking teachers to meet the demand for English in primary schools, these policies seem to indicate the government's commitment to strengthening English in primary schools. However, the Major Policies and Plans for 2011(MEST, 2010) did not specifically mention English at all.

The policies outlined above have been far from universally endorsed, however. J. Lee (2004) points out that the initial policy was controversial for both political and pedagogical reasons. Opponents pointed to the lack of trained teachers and the consequent need for teacher training as well as to the lack of resources in schools. 
Bao(1995, cited in J. Lee, 2004) also identifies issues related to the threat to South Korean national identity, the extra burden placed on parents and the lack of strong evidence that children learn languages better the earlier they start. Indeed, the assumed benefits of an early start remain unproven (see, for example, Nikolov \& Mihaljevic Djigunovic, 2006; Pinter, 2006), especially in contexts such as South Korea where input is limited, as opposed to contexts where language immersion is the norm (Larson-Hall, 2008).

It is against this background that primary school teachers of English in South Korea face a number of key pedagogical issues. These issues are discussed in the following sections, using Kaplan and Baldauf's(2005) language-in-education framework. The focus will be on the situation in South Korea, but with reference to other countries where relevant.

\section{Framework}

Language-in-education is one of four activity types in language policy and planning, the others being status planning, corpus planning and prestige planning (Baldauf, 2005; Hornberger, 2006; Ricento \& Hornberger, 1996). Baldauf (2005, p.961) defines language-in-education planning as focusing on "those user-related learning decisions that need to be made to develop language education programs and teach a language(s) for various purposes”. Baldauf and Kaplan(Baldauf, 2005; Kaplan \& Baldauf, 2005) have identified seven components in a language-in-education framework which together determine the success of policy: access policy, personnel policy, curriculum policy, methodology and materials policy, resourcing policy, community policy and evaluation policy. 
This article focuses on three of these as most relevant to teachers and teaching practices:

(1) personnel policy: the human resources made available, in particular teacher recruitment and training;

(2) curriculum policy: the objectives of language teaching/learning and what is to be taught;

(3) methodology and materials policy: what language teaching approach and what materials are to be used for teaching and learning;

In the following section, findings from previous research concerning the policy, planning and implementation of teaching English to young learnersin each of these threeareas are reviewed.

\section{Issues in teaching English to young learners}

\section{Personnel Policy}

The two key aspects of personnel policy are instrumental in the success of policy implementation: recruitment and training of teachers and their language proficiency.

\section{Recruitment and Training}

Following the introduction of English into primary schools, many countries lacked a sufficient number of fully trained teachers (ie to teach English and to teach in the primary sector) (G. Hu, 2005a; Y. Hu, 2007; Nunan, 2003; Nur, 2003), a situation that was especially acute in poor or rural areas.

Solutions to this problem have varied both from country to country and from school to school. However, one common initial solution was to use regular classroom teachers who spoke some English, either with or without training. This was the case in 
China, for example (Y. Hu, 2007), and also in South Korea. The South Korean government has invested a large amount of time and money in teacher training $(\mathrm{H}$. Lee, 2010), initially offering in-service training to regular class teachers in the form of a minimum of 120 to 240 hours in order to improve their language and teaching skills (Shim \& Baik, 2003). Moreover, new teachers have increasingly received pre-service training as English teachers (Butler, 2004).

However, lack of sufficient or appropriate training is still seen as problematic by many teachers. H. Lee (2010) refers to 'theory-based teacher education courses' in South Korea, in which teachers do not experience 'real change'. By not being able to put changes into practice, teachers may fail to gain the sort of competence and confidence to implement new government policies in the classroom (H. Lee, 2010).

A number of governments in Asia have also attempted to improve the recruitment situation by 'importing' native speaker teachers. This move is a partly to address the lack of qualified primary school teachers of English but also to increase the motivation of children to learn English (Jeon, 2009). This is the case of the NET scheme in Hong Kong, and the JET scheme in Japan (Nunan, 2003). The Korean government runs two schemes a) English Programme in Korea (EPIK) for graduates and b) Teach and Learn in Korea scheme (TaLK) for undergraduates. The latter is focused especially on placing teachers in schools in rural areas ${ }^{\mathrm{i}}$.

However, such schemes may not represent the best solution to the problems they aim to address. Jeon (2009) outlines some of the issues with EPIK. Firstly, there is the questionable assumption on which such programmes are based, namely that English is best taught through English only and by native speakers, defined as citizens of a small group of countries (Australia, Canada, Ireland, New Zealand, South Africa, the UK, and the USA). Secondly, such schemes often rely on volunteer teachers who tend to be 
untrained(Kaplan \& Baldauf, 1997). As a result, the pedagogic experiences of the teachers involved, both the native-speakers and the Korean teachers are often unsatisfactory (Choi, 2007; Jeon, 2009).

\section{Teachers' Level of English Proficiency}

The problem of teachers' low proficiency level in English or their lack of confidence in their English ability is almost universally identified in previous research (see, for example, Baker, 2008; Butler, 2004; Hoque, 2009; Kuchah, 2009; W. L. Lee, 2009; Li, 1998; Littlewood, 2007; Nunan, 2003; Prapaisit de Segovia \& Hardison, 2008). The perceived demands of new methods, such as teaching in the target language, can contribute to a lack of confidence, particularly in speaking and listening skills. For example, a South Korean $5^{\text {th }}$ grade teacher in Butler's study said: "I hesitate to create an open-ended situation. To be honest with you, I often do not know how to say things correctly in English when I am asked by my students!" (Butler, 2005:435).

However, there is no consensus as to what level of proficiency and fluency teachers really need in order to teach in primary schools. It may be that the real issue is not the teachers' lack of proficiency, which may be adequate for teaching young learners, but rather a lack of confidence predicated on the belief that native-like competence is required to teach communicatively. Shim and Baik(2003, p.243)thus conclude that

\footnotetext{
The greatest obstacle for English teachers in Korea is not in their lack of English proficiency but in their belief that an English teacher has to speak English at the native-speaker level in order to conduct a class in English.
}

\section{Curriculum, Methods and Materials Policy}


In line with Baldauf et al. (2011) curriculum policy and methods and materials policy will be discussed together, given their close relationship in the implementation of early language learning.

\section{Approaches to Language Teaching}

Perhaps the most important and most complex of the policy decisions impacting on the classroom concerns the pedagogic approach recommended by governments for teaching English to young learners. As Liddicoat(2004) notes, governments intervene in approaches to language teaching when there is a perceived problem in current teaching methods. A change in approach is often seen as panacea, with little or no consideration for the complex factors involved in what is often a radical change. Thus, in response to the perceived global demand for communication in English, and to the persistence of the grammar-translation method in secondary schools, the new primary English curriculum in South Korea, in line with many other countries, has emphasised communicative competence (Li, 1998; Mitchell \& Lee, 2003).

Communicative Language Teaching (CLT), the most commonly endorsed approach, has its origins in English as a Foreign Language teaching for adults in western countries where groups are small and classrooms well-equipped (Enever \& Moon, 2009). It is not, therefore, necessarily appropriate for teaching children in overcrowded classrooms with very different educational traditions (G. Hu, 2002, 2005b; McKay, 2003). Moreover, the approach may be misunderstood by teachers, who have received little or no training in its theoretical underpinnings and especially in its practical applications(Butler, 2005; Li, 1998; Littlewood, 2007). The South Korean secondary school teachers in Li's (1998) study, for example, believed that CLT meant focusing solely on fluency and ignoring accuracy. The South Korean, Taiwanese and Japanese teachers in Butler's (2005) study all stated that they had used games, songs, 
chants and role plays in their classes, as suggested by their governments, but some indicated that they were not sure what the purpose of such activities was.

The consequence is often a gap between pedagogic policy and classroom practice (G. Hu, 2005a, 2005b; Nikolov, 2009b; Nunan, 2003). The typical pragmatic response from teachers is the adoption of so-called weak forms of CLT (Carless, 2003; Ho \& Wong, 2003b), whereby teachers interpret the approaches according to their local context (Mitchell \& Lee, 2003), using, for example, communicative activities to practise discrete language items (Carless, 2004; Mitchell \& Lee, 2003; Xinmin \& Adamson, 2003). Indeed, both Li (1998) and Littlewood(2007) conclude that the advice to teachers should be to adapt rather than adopt, and G. Hu (2005b, p.655) calls for "an informed pedagogical eclecticism".

\section{Materials and Learning and Teaching Resources}

Until relativelyrecently in South Korea there was one prescribed textbook for each grade (Butler, 2004) and this is also the case in, for example, Malaysia (Pandian, 2003). In other countries, there is a range of government-approved textbooks for teachers to choose from, as, for example, in China (G. Hu, 2005a) and Singapore (Mee, 2003).

A more recent development has been the promotion in some countries, such as South Korea, China and Taiwan, of technological support and multi-media packages, in the belief that these can go some way towards compensating for the lack of qualified teachers or their low language proficiency. Mitchell and Lee (2003) report that the South Korean teacher in their study used a package centred on a video which modelled all the language, together with a course book and teacher's manual which gave a detailed guide to implementation. Mitchell and Lee (2003, p.40) describe it as "a complete kit, usable by teachers with limited English". A number of other writers have also argued that such resources can offer much support to teachers (Y. Hu, 2007; 
Nunan, 2003), although there is evidence that materials alone may have little or no effect on changing teaching practices, unless adequate training is also offered (Humphries, 2011; Nur, 2003).

\section{Classroom-Based Factors}

Large classes are common in many countries (Ho, 2003; Wedgwood, 2007) and teachers believe this makes it difficult or impossible to introduce the more learnercentred teaching required by CLT. Difficulties include, for example, monitoring students' language use (Li, 1998) and using pairwork and groupwork(Hoque, 2009).

Problems of control and discipline connected with learner-centred teaching in large classes have also been raised (Butler, 2005; Carless, 2004; Littlewood, 2007). Butler (2005) refers to the difficulties in what she calls 'classroom harmonization', or aligning learning and teaching with the context through both the physical environment of the classroom and variables such as roles and behaviours. Butler (2005) found that some teachers see this as particularly challenging during English classes because of the interactive way they are expected to teach, which is different to teaching methods used in other subjects.

\section{Learner Factors}

Many teachers believe that they are limited in what they can do in the primary classroom because of learners' low levels of proficiency (Li, 1998). Moreover, learners' expectations about what to learn, such as the importance of grammar for examination purposes (Prapaisit de Segovia \& Hardison, 2008) and how to learn English may conflict with what teachers are expected to do (Ho, 2003). However, Carless (2003) points out that mismatches in expectations may be more to do with the teachers' lack of 
understanding of CLT and their ability to select appropriate tasks than with any real incompatibility with the demands of tests or the expectations of students.

Another issue frequently reported is an apparent lack of motivation and interest in English on the part of learners, who may not see any need to learn the language or simply do not see mastery of it as attainable ( $\mathrm{Li}, 1998)$. This may be particularly acute in rural areas where learners have little contact with foreigners and therefore little perceived need to learn to communicate in English (Ho, 2003). Consequently, teacherfronted classes with a focus on grammar and memorisation are often preferred by learners(G. Hu, 2005b; Li, 1998; Prapaisit de Segovia \& Hardison, 2008).

Although the South Korean government has undoubtedly taken a number of important steps to address the major issues that such an innovative national policy inevitably raises, the question remains as to what the situation is today, more than 15 years since the policy was introduced, especially as it is experienced by those most closely involved in implementation - the teachers themselves.

\section{The Study}

This study is part of a much larger, globalstudy that investigated current practices in teaching English to young learners around the world(Garton, Copland, \& Burns, 2011). The purpose of the data presented here is to obtain, through an interpretive-exploratory paradigm (see, for example, Grotjahn, 1987), an insider, or emic, perspective (van Lier, 1988; Watson-Gegeo, 1988) on the key constructs of early language learning policy and practices in South Korea today.

A mixed-method research design was used (see, for example, Creswell, 2003; Dörnyei, 2007), drawing on both quantitative and qualitative approaches to enable a more rounded picture of policy and practice to emerge as well as complementary 
findings to be presented. The mixed methods design adopted consisted of: i) a survey of perceptions of practices from a sample of primary school teachers of English; ii) a small-scale case study of the context, practices and perceptions of one South Korean primary school teacher.

The cross-sectional survey was provided both electronically through Survey Monkey, and via hard copy to accommodate limited or no technological access. The survey wasadministered in English as it was aimed at primary school teachers around the world. While every care was taken to phrase questions as clearly and simply as possible, it must be recognised that the use of English is likely to have limited respondents to those teachers with a certain level of language proficiency. 125 survey responses from teachers working in Korean primary schools were obtained, with the number of answers to each closed question ranging from 125 to 62 . The number of responses is clearly small compared to the total number of primary school teachers of English in Korea and, as the survey used non-probability 'opportunity' sampling, it should be recognised that responses represent reported practices of a small group of teachers rather than providing general conclusions about actual practices.

The survey items drew on the literature on survey design (see, for example, Dörnyei, 2009; Oppenheim, 1992) and consisted of six sections, which required information relating to: 1) demographics (location/type of school, qualifications/years of experience, English proficiency); 2) English teaching in the country; 3) the school; 4) the class and activities used; 5) syllabus planning; 6) teachers' opinions about challenges, improvement and change. A range of closed, ranked and open-ended items was used in order to gain mainly quantitative but also some qualitative responses.

Qualitative data were obtained in the form of a small-scale case study of a South Korean primary school teacher. The data consist of: 
(1) An initial interview for preliminary information about the national and local context, class/students, the purpose and plans for the lesson, and for any other information relevant to the observation. The teacher also provided relevant documents (policy and syllabus documents and classroom materials).

(2) A classroom observation which was audio-recorded, with field notes and photographs taken by the researcher.

(3) A post-observation interview to discuss the lesson and any other issues. Transcripts were made of all the interviews.

The class observed was a mixed Grades 1 and 2 after-school class in a state school just outside the centre of Seoul. The teacher, Soon-yi (a pseudonym), was female and in her 40s. Consent was obtained from both the school principle and the teacher.

The case study provides a snap-shot of current practices in one location on one teaching occasion. It illuminates and complements the quantitative data but cannot claim to be generalised interpretations of ongoing practices in the classrooms concerned or in the wider practices at national levels.

\section{Main findings}

\section{Portrait of a Teacher of English to Young Learners in South Korea}

The vast majority of the 125 survey respondents were female (91\%) and were Korean (92\%), with the remainder from the USA or the UK. Most worked in state schools $(81.2 \%)$ in urban areas (83\%) and taught grade five or grade six (81\%). Figure 1 below shows that overall the level of education of respondents was quite high, with $95 \%$ educated to at least bachelor's level.

Insert Figure 1 - Level of education of survey respondents here 
Figure 2 shows that just over half the respondents were in their 30 s and a quarter in their 40s while Figure 3 shows thatnearly $63 \%$ had been teaching English in primary school for four years or less.

Insert Figure 2 Age of survey respondents here Insert Figure 3 - Number of years as a primary school teacher of English here

Given the age of the respondents compared to the short time they had been teaching English, the implication is that they did not start their careers in this role. It can be assumed that this is a reflection of the initial personnel policy outlined above whereby the government initially used regular class teachers to teach English (see for example, Shim and Baik, 2003 and also below).

\section{Implementation of Personnel Policy}

Recruitment and training

Althoughprevious research has reported that in Korea it is mainly regular class teachers who teach English (Shim \&Baik 2003), according to the survey results nearly $63 \%$ of the respondents report working in a school where one teacher teaches all the subjects except English, implying that there are specialist English teachers. The case study teacher, for example, said that her school had three specialist English teachers for the regular classes.

Interestingly, not all the survey respondents felt that recruiting specialist English teachers was the best solution. One teacher wroteOnly few teachers teach English as a classroom teacher. I hope classroom teachers teach English as well as other subjects to give more chances to students to learn more English. 
Seven respondents said that Korean and native-speaker teachers co-taught in their school. There is evidence from Soon-yi that this can be problematic, as discussed above: We have native English speakers as assistants, they don't have certificate as a teacher, but some are, some have. So even though they speak perfect English, they don't know how to teach, there are some native teachers who don't know how to manage the kids. It's a problem. And co-teaching system sounds very ideal but in reality there are a lot of problems. If they don't understand each other's culture it's very difficult to communicate properly.

In terms of training, $70 \%$ of respondents report receiving pre-service training, while $83 \%$ report receiving in-service training. The 60 responses to the open question asking what sort of training had been received were often not specific. However, the government, the Seoul Metropolitan Office of Education (SMOE), local universities and the British Council were all mentioned as organisers of training courses. A number of teachers mentioned 'intensive courses' of 60,120 and 180 hours. Others mentioned methodology courses that focused on the four skills and activities for YLs. The following comment seems typical: The training was about how to teach 4 skills and to teach English through songs, dramas etc. There were trainings were about teaching methods and how to be a good teacher trainer.

Three teachers also specified that they had received training for Teaching English in English (TETE), while two teachers said they had completed the Cambridge ESOL International Certificate of English Language Teaching (ICELT), which is run by the British Council in Seoul. Two teachers had completed the Trainer of Teachers (ToT) course also run by the British Council in Seoul and supported by the Seoul authorities. Soon-yi also participated in this project, which she reported was a four year project aiming to create a trickle-down effect by which a group of teachers who would train others who would then in turn train colleagues and so on. However, at the time of 
the research the scheme had been abandoned, although efforts were being made to persuade the SMOE to reprise it.

While the situation outlined above shows a number of positive professional development initiatives and possibilities forprimary English teachers, training in new teaching methodologies was ranked second in the closed question concerning which factors would most improve the teachers' situation. However, it was less of a concern than a number of other issues in the answers to the open questions regarding challenges faced. It seems likely that, while training is clearly still an issue, there are other factors that are of greater importance, at least to the teachers in this research.

Overall, the data on the implementation of personnel policy seem to reflect Kaplan and Baldauf's (1997:130-131) trajectory for personnel policy following the introduction of innovative language-in-education polices: initial retraining of existing teachers and the hiring of native-speaker teachers as immediate measures while a new generation of specialist teachers is trained. As Soon-yi explained:

Now there are so many young teachers, and learning English is ... compulsory in the university, and they should pass English interview and teaching practical test to be a teacher, so their English and teaching skills are pretty good. So it's very important I think. And some old teachers, it's really hard to learn a new language, right? So ... they want to retire quickly, because of computers and English.

Thus, as Butler (2004) observed, South Korean primary schools are increasingly able to draw on trained English teachers, although the extent to which there is equal access to these teachers across the country would need further investigation.On the other hand, the effective use of native-speaker teachers is a personnel policy issue that still needs to be addressed. 


\section{English Proficiency}

When asked to evaluate their level of English, nearly half the respondents report their level to be intermediate level or lower. Lack of English proficiency is a matter of real concern for the Korean teachers. When asked to rank eight factors that would improve learning and teaching in their contexts, improvements in their level of English was ranked third, compared to sixth globally (Garton et al, 2011).

Moreover, of the 46 teachers who responded to the open question asking what their biggest challenge was, nine pointed to their lack of English proficiency. For example, one respondent replied that his/her biggest challenge was When I think I have to speak perfect English.In particular, the TETE initiative may cause problems for teachers and two teachers in the questionnaire explicitly identified this as their biggest challenge: Teaching English through English only. Especially giving introduction is the most difficult part.

It is not possible to ascertain from these data whether the teachers' level of English is actually low, or whether they lack confidence. However, this difference may be immaterial when it comes to considering the effects on teaching young learners. The belief that near native-speaker competence is necessary in order to teach communicatively can mean teacherswhose first language is not English feel inadequate to teach communicatively, whatever their level.

These findings raise two key issues. First, the question remains as to exactly what level of language competence is necessary to teach English at primary level. Cameron (2003:111) maintains that primary English teachers need 'a high level of fluency and a wide knowledge of vocabulary' yet Garton et al (2011) report on classes conducted effectively in English by teachers with relatively limited language competence. Second, current research is challenging the insistence on target language 
only classrooms(see, for example, Brooks-Lewis, 2009)with a move towards focusing on to how learners' first language can be used effectively to teach the target language (see, for example, Copland \& Neokleous, 2011; Littlewood \& Yu, 2011).

The level of English proficiency is therefore an on-going issue in personnel policy in Korea, and indeed more widely, with important implications for teacher education (see discussion below).

\section{Implementation of curriculum, methods and materials policy}

\section{Curriculum and materials}

Perhaps unsurprisingly, given the centralised control over English language teaching in Korea, the national syllabus was rated either very useful or somewhat useful for lesson planning purposes by nearly $88 \%$ of the teachers. Local documents such as the school curriculum and class schemes of work were also seen as useful by the majority of teachers. However, the most influential document was the lesson plan, with nearly $96 \%$ of rating this as useful or very useful. The course book was also seen as extremely important as were supplementary materials (which were not specified, but can be taken to mean the materials included in the course book pack ${ }^{\mathrm{ii}}$ ). Only two teachers expressed a wish to change the coursebook.

Given that the course book is prescribed by the government and the lesson plans are likely to focus on the use of the book, overall, it can be seen that the Korean teachers follow the National Curriculum closely.

Kaplan and Baldauf (1997) point out that one of the main issues in curriculum policy is how many hours of the curriculum can be dedicated to language instruction and that the number of hours will almost always be inadequate. There was some evidence of this in the survey with one questionnaire respondent reportingSometimes it's 
frustrating when I notice that I am hurry to follow up the national curriculum. Although the case study teacher was observed teaching after-school classes where she was free to decide her own syllabus, she pointed out:

the syllabus is different but the activities are fairly similar. I have some of my favourite activities, so I use randomly of them, but the syllabus is totally different because the regular class follows the national curriculum and we have text books, so I cannot neglect all the syllabus

However, overall it can be concluded that neither the implementation of curriculum policy nor of materials policy emerged as major issues for the teachers in the study.

\section{Method}

Classroom activities. To obtain an idea of what happens in primary English classrooms, survey respondents were asked to indicate, using a 5-point Likert scale, the activities they used most frequently from a list of 24 . Table 1 shows the percentage of teachers who responded that they used the activities 'every lesson' or 'often' or that they used them 'rarely or 'never'.

The data show a relatively frequent use of 'communicative' activities, with playing games as the most popular activity. Although children reading out loud and repeating after the teacher are both popular, more 'traditional' activities most frequently used in the larger global survey, such as grammar exercises, filling in the gaps and memorisation do not figure in the South Korean list.

Only five activities were never or rarely used by the majority of the teachers, again a combination of 'communicative' and 'traditional' activities.

Insert Table 1: Frequency of use of activities here 
The popularity of listening to the $\mathrm{CD}$ or tape recorder may be a result of teachers' reported lack of confidence in their own use of English and preference for providing children with a native speaker model via a recording. This finding is borne out by previous research (Y. Hu, 2007; Nunan, 2003) and indeed, Mitchell and Lee (2003) point out that the government-approved textbooks in Korea come with a CD-rom.

The high level of reported use of TV/video as well as CD/tape recorder may imply that Korean teachers have access to a wide range of technology. Soon-yi's classroom was equipped with state-of-the-art computer and giant TV screen, which the teacher used effectively for story-telling. However, use of the computer, which was one of the options in the survey, does not figure in the table above. It could be that computer rooms, where children can use computers themselves, are lacking in primary schools, or they are not generally used for English classes. However, it could also be that computers are no longer a novelty for children and teachers prefer to use more 'traditional' equipment, including paper and crayons $s^{\mathrm{iii}}$

There is some evidence from these data, therefore, that the teachers in the survey are adopting a weak form of the communicative approach that government policy advocates, as suggested in previous research (Carless 2003; Ho and Wong 2003). This may be an indication that the training now available for teacher is proving increasingly effective. However, it is also noticeable that more unstructured, creative activities such as creative writing, project work and making things hardly figure in the pedagogy of the Korean teachers. Given the time-consuming nature of such activities, their lack of use is likely to be a result of the strictly prescribed curriculum and materials, which may prove a barrier to the full implementation of methods policy. 
Classroom-based and learner factors. When asked about factors that would improve learning and teaching in their contexts, smaller class size was ranked as the most important by the respondents. Moreover, four teachers reported large classes as their biggest challenge, while five identified this factor as the aspect of their situation they would most like to change.

The questionnaire data showed that class sizes are generally bigger in Korea than in the global sample, with $47 \%$ of classes having $21-30$ children and $40 \%$ having $31-40$ children (globally, $30.8 \%$ of classes have $11-20$ children, $38.4 \%$ have $21-30$ children and only 13.5 have $31-40$ children, see Garton et al. 2011).

Large classes are a potential obstacle to the implementation of the communicative teaching required by the government (Hoque, 2009; $\mathrm{Li}, 1998$ ) and remain an important challenge for Korean teachers. As one respondent said: There are too much students in a class to take care their competence.

Three further important classroom-based and learner factors were identified by the teachers: discipline problems, motivation and mixed level classes. As well as being related to class size, these factors were also seen as very closely interrelated to each other.

Maintaining discipline was reported as the biggest challenge by nine respondents. For example one teacher said his/her major problem wasTo discipline children specially the 6th graders specially boys. Large classes were seen as an issue in maintaining discipline, as one teacher reported his/her biggest challenge was controlling many children.Motivation was also identified by nine teachers as an important issue. As one stated, his/her biggest challenge wasKeep the students interested in English and motivate them. Moreover, motivation was seen as related to discipline: Dealing with the older children who sometimes don't want to be learning anything. 
Problems of large classes, motivation and discipline in connection with the introduction of learner-centred teaching have been widely reported in previous research (see for example, Butler,2005; Carless, 2004; Ho, 2003; Li, 1998; Littlewood, 2007). It seems that these factors still constitute a potential obstacle to the successful implementation of methods policy in Korea today.

However, there is one majorissuereported by teachers not only in Korea but around the world (Garton et al. 2011)that does not seem to have been identified by previous research: mixed level classes, referring to both mixed ability and mixed proficiency. Ten teachers indicated mixed level classes as their biggest challenge, for example: Slow learners. It's so hard to teach them to reach a goal I set and different levels in English proficiency.

Although the challenge of dealing with mixed level classes is not unique to Korean teachers, the conditions that lead to mixed proficiency are quite specific. One teacher stated clearly that there are too big gap between fast learners and slow learners causes of the private education.

Han (2010, cited in Humphries, 2011) maintains that 70\% of families in Seoul make use of private English educationwith a figure of $40 \%$ in the rest of the country. Jeon (2009) cites a newspaper report that Koreans spend five billion dollars a year on educating their children abroad, which is equivalent to nearly $20 \%$ of the government's education budget. This situation has led to the Korean phenomenon of 'wild goose daddies' (W. L. Lee, 2009), whereby fathers stay in Korea to earn money while their wives take the children aboard to study in English-speaking countries. The gap in expenditure on English between the rich and poor and between urban and rural areas is growing, leading to an 'English divide' (Kang, 2012) and is a potential cause of social tension(see Piller \& Cho, 2013 for a critical view of English language policy in Korea). 
The increasing power of the private sector is of concern to MEST, which, in its Major Policies and Plans for 2010 (MEST, 2009), explicitly stated that it aimed to reduce spending on private education by improving the provision of state education and in particular for English. The MEST website currently reports that its policies seem to be succeeding with spending on private education in general, which had been increasing by $10 \%$ each year, decreasing by $3.5 \%$ in 2010 for the first time ${ }^{\text {iv }}$. However, Kang (2012, p.71) challenges t hese claims.

In this study, therefore, classroom-based and learner factors were identified as the biggest barrier to the implementation of government policy, particularly methods policy. Yet these aspects of policy implementation have perhaps been given less attention in the literature.

\section{Discussion and Implications}

The overall results of the study reported can be summarised as follows:

(1) Personnel policy has been partially successful with initial problems in training and recruitment being addressed while language proficiency remains an issue.

(2) Curriculum and materials policy is not seen as problem by the teachers in this study, although there is some pressure to complete the government syllabus.

(3) There remain major issues in the implementation of methods policy, particularly around classroom-based and learner-based factors.

It is noticeable, therefore, that the view on a number of levels tends to be rather positive, compared to many other countries. J. Lee (2009:101) concludes

Primary English Language Teaching has, overall, been surprisingly successful, particularly given the poorly prepared way in which it was introduced just 10 years ago. For this we can thank an all round generally good educational infrastructure. 
However, the data presented reveal new challenges and issues that have not previously gained attention, and a number of implications can be identified.

\section{Implications for personnel policy}

Although training opportunities seem to be fairly widely available, the number of teachers who feel they need more training is of some concern. Therefore, the effectiveness of training initiatives needs to be evaluated. As noted by H. Lee (2010), teaching teachers about new methodologies may not lead to their implementation if a) the teachers do not understand the underlying rationale and b) if they are not given the chance to put theory into practice under guidance and supervision. Moreover, the survey data would appear to show that most training opportunities take place in Seoul, and while this finding could be a result of the survey sample, further investigation is needed into equality of opportunity for access to training outside the capital.

The use of native-speaker English teachers is still advocated by the government. However, both previous research (Jeon, 2009; Choi 2007) and the study reported here show a need for careful evaluation of these schemes with a view to establishing minimum training for native-speaker teachers and how they can be used most constructively and effectively in a team-teaching context.

The English language proficiency of South Korean primary school teachers is highly varied but many feel that their level is inadequate. This is a barrier to the implementation of government policy and there is clearly still a need for English language development for a large number of teachers. However, there is also a need for a change in emphasis away from a focus on English-only classrooms to focus on how to use the L1 effectively. This would not only provide greater learning opportunities for 
learners(Butzkamm, 2003)but would also eliminate the feelings of guilt and inadequacy that many teachers report (Copland and Neoleous, 2011).

\section{Implications for methods policy}

In terms of classroom pedagogy, the study shows that Korean primary school teachers appear to be using activities that fulfil the government policy of developing communicative competence in listening and speaking and, although there is some evidence of more traditional activities, grammar-based activities are rarely used.

The implication is that the teachers have adopted what has been called a weak version of communicative language teaching (Carless, 2003; Ho and Wong 2003). Rather than simply adopt new 'western' methods that have been imposed by government policy, it is likely that teachers have taken a more pragmatic approach and have adapted learnercentred teaching in a way that is more suited to the local context(Jin \& Cortazzi, 2006; Littlewood, 2007),indicating the type of pedagogical eclecticism called for by G. Hu (2005a, p.655). Teacher training therefore needs to focus on ensuring that such eclecticism is also 'informed' (ibid.)

Although motivation is addressed in the English language teaching literature, discipline and mixed level classes are rarely discussed, yet the results of this study show that these are issues of great concern to teachers of young learners in South Korea, and elsewhere. Although not limited to large classes, these factors are certainly exacerbated by teaching many children.

\section{Addressing the issues}

Kaplan and Baldauf (1997, p.129) underline the need for smaller classes to ensure that language learning is effective. While a reduction in class size is a matter for 
governments and education departments, schools need to find ways of ensuring smaller groups or more effective teaching through, for example, better use of team-teaching with native-speaker teachers or the use of other teaching assistance where possible (e.g. teaching assistants, class teachers, volunteers) to help keep children on-task and work with lower level children.Although not present in the observed lesson, Soon-yi had a university student volunteer who came to her classes once a week and worked particularly with the lower level children. This initiative was viewed positively by the teacher.

While basic pre-service training appears to be successful in preparing a new generation of specialist English teachers, there is now a need for more targeted training, whether pre- or in-service. Such training needs to focus on unresolved aspects of methods policy and address the new challenges that are highlighted as important by teachers, presenting effective strategies to deal with key issues. These include managing large classes and dealing with discipline; dealing with multi-level classes, developing and maintaining motivation; identifying effective ways of working with native speaker teachers of English and effective use of L1 and L2 in the classroom.

\section{Conclusion}

This article has examined the situation in Teaching English to Young Learners in South Korea, a relatively early adopter of early language learning polices. Overall, the picture that emerges is quite positive with a number of initial challenges in the area of personnel, curriculum and materials policies that appear to have been addressed by the government and other organisations, at least to some extent. However, the study has revealed some continuing issues, such as the teachers' level of English proficiency, together with some new challenges,particularly in methods policy. 
The clear lesson from the research reported here is that, if governments wish to be successful in their introduction of languages into the primary curriculum, initial investment in policy is simply a first step. Continued resources are necessary to address the ever-changing challenges faced by teachers and to ensure positive outcomes in early language learning.

\section{Acknowledgments}

This article is an output from the ELT Research Award scheme funded by the British Council to promote innovation in English language teaching research. The views expressed are not necessarily those of the British Council.

\section{References}

Ali, N.L., Hamid, M.O., \& Moni, K. (2011). English in primary education in Malaysia: policies, outcomes and stakeholders' lived experiences. Current Issues in Language Planning, 12(2), 147-166.

Baker, W. (2008). A critical examination of ELT in Thailand: the role of cultural awareness. RELC Journal, 39(1), 131-146.

Baldauf, R.B. (2005). Language planning and policy and language rights. In E. Hinkel (Ed.), Handbook of Research in Second Language Teaching and Learning. Mahwah, N.J.: Lawrence Erlbaum.

Baldauf, R.B., Kaplan, R.B., Kamwangamalu, N., \& Bryant, P. (2011). Success or failure of primary second/foreign language programmes in Asia: what do the data tell us? Current Issues in Language Planning, 12(2), 309-323.

Brooks-Lewis, K.A. (2009). Adult learners' perceptions of the incorporation of their L1 in foreign language teaching and learning. Applied Linguistics, 30(2), 216-235.

Butler, Y. G. (2004). What level of English proficiency do elementary school teachers need to attain to teach EFL? Case studies from Korea, Taiwan and Japan. TESOL Quarterly, 38(2), 245-278.

Butler, Y. G. (2005). Comparative perspectives towards communicative activities among elementary school teachers in South Korea, Japan and Taiwan. Language Teaching Research, 9(4), 423-446.

Butler, Y. G., \& Iino, M. (2005). Current Japanese reforms in English language education: the 2003 "Action Plan". Language Policy, 4, $25-45$.

Butzkamm, W. (2003). We only learn language once. The role of the mother tongue in FL classrooms: death of a dogma. Language Learning Journal, 28(1), 29-39.

Carless, D.R. (1998). A case study of curriculum implementation in Hong Kong. System, 26(3), 353-368.

Carless, D.R. (2003). Factors in the implementation of task-based teaching in primary schools. System, 31, 485-500.

Carless, D.R. (2004). Issues in teachers' reinterpretations of task-based innovations in primary schools. TESOL Quarterly, 38(4), 639-661. 
Chen, A. (2011). Parents' perspectives on the effects of the primary EFL education policy in Taiwan. Current Issues in Language Planning, 12(2), 205-224.

Choi, K.H. (2007). The language policy issues in Seoul: hiring native speaker English teachers. www2.hawaii.edu/ cmhiggin/.../Choi\%20Lang\%20Policy\%20660.doc

Copland, F., \& Neokleous, G. (2011). L1 to teach L2: complexities and contradictions. ELT Journal, 65(3), 270-280.

Creswell, J. (2003). Research Design: Qualitative, Quantitative, and Mixed Methods Approaches. Thousand Oaks, CA: Sage Publications.

Dörnyei, Z. (2007). Research methods in Applied Linguistics. Oxford: Oxford University Press.

Dörnyei, Z. (2009). Questionnaires in Second Language Research:Construction, Administration and Processing. 2nd Edition (2nd ed.). New York: Lawrence Erlbaum.

Enever, J., \& Moon, J. (2009). New global contexts for teaching Primary ELT: change and challenge. In J. Enever, J. Moon \& U. Raman (Eds.), Young Learner English Language Policy and Implementation: International Perspectives (pp. 5-21). Reading: Garnet Education.

Foley, J.A. (2005). English in Thailand. RELC Journal, 36(2), 223-234.

Garton, S., Copland, F., \& Burns, A. (2011). Investigating Global Practices in Teaching English to Young Learners. In B. Council (Ed.), ELT Research Papers 11-01. London: British Council.

Grotjahn, R. (1987). On the methodological basis of introspective method. In C. Faerch \& G. Kasper (Eds.), Introspection in Second Language Research (pp. 54-81). Clevedon: Multilingual Matters.

Ho, W.K. (2003). English language teaching in Asia today: An overview. In W. K. Ho \& R. Y. L. Wong (Eds.), English Language Teaching in East Asia Today: Changing Policies and Practices (pp. 1-32). Singapore: Eastern Universities Press.

Ho, W.K., \& Wong, R.Y.L. (2003b). Prologue: aim, scope and concepts. In W. K. Ho \& R. Y. L. Wong (Eds.), English Language Teaching in East Asia Today: Changing Policies and Practices (pp. 463-473). Singapore: Eastern Universities Press.

Hoque, S. (2009). Teaching English in primary schools in Bangladesh: Competencies and achievements. In J. Enever, J. Moon \& U. Raman (Eds.), Young Learner English Language Policy and Implementation: International Perspectives (pp. 61-69). Reading: Garnet Education.

Hornberger, N.H. (2006). Frameworks and models in language policy and planning. In T. Ricento (Ed.), An Introduction to Language Policy: Theory and Method (pp. 24-41). Malden, MA: Blackwell.

Hu, G. (2002). Potential cultural resistance to pedagogical imports: the case of communicative language teaching in China. Language, Culture and Curriculum, 15(2), 93-105.

Hu, G. (2005a). English Language Education in China: policies, progress and problems. Language Policy, 4(5-24).

$\mathrm{Hu}, \mathrm{G}$. (2005b). Contextual influences on instructional practices: a Chinese case for an ecological approach to ELT. TESOL Quarterly, 39(4), 635-660.

$\mathrm{Hu}, \mathrm{Y}$. . (2007). China's foreign language policy on primary English education: What's behind it? Language Policy, 6, 359-376. 
Humphries, S. (2011). Exploring the impact of the inotroduction of new EFL textbooks on teachers' practices and attitutdes at a technical college in Japan. (PhD PhD thesis), Unpublished $\mathrm{PhD}$ thesis, Macquarie University.

Jeon, M. (2009). Globalization and native English speakers in English Programme in Korea (EPIK). Language, Culture and Curriculum, 22(3), 231-243.

Jin, L., \& Cortazzi, M. (2006). Changing practices in Chinese cultures of learning. Language, Culture and Curriculum, 19(1), 5-20.

Kang, D-M. (2008). The classroom language use of a Korean elementary school EFL teacher: another look at TETE. System, 36, 214-226.

Kang, H.D. (2012). Primary school English education in Korea. In B. Spolsky \& Y.-I. Moon (Eds.), Primary School English-language Education in Asia (pp. 59-82). New York: Routledge.

Kaplan, R.B., \& Baldauf, R.B. (1997). Language Planning: From Practice to Theory. Clevedon: Multilingual Matters.

Kaplan, R.B., \& Baldauf, R.B. (2005). Language-in-Education Policy and Planning. In E. Hinkel (Ed.), Handbook of Research in Second Language Teaching and Learning (pp. 1013-1034). Mahwah, N.J.: Lawrence Erlbum.

Kuchah, K. (2009). Early bilingualism in Cameroon: Where politics and education meet. In J. Enever, J. Moon \& U. Raman (Eds.), Young Learner English Language Policy and Implementation: International Perspectives (pp. 87-94). Reading: Garnet Education.

Larson-Hall. (2008). Weighing the benefits of studying a foreign language at a younger starting age in a minimal input situation. Second Language Research, 24, 35-63.

Lee, H. (2010). Analyzing the effecs of collaborative action research from the teacher identity perspective. Teaching English, 65(1), 161-188.

Lee, J. (2004). Multi-layered aspects of language policy:implementing English education at elementary schools in Korea. Working Papers in Educational Linguistics, 20(1), 71-87.

Lee, W. L. (2009). Primary English Language Teaching (ELT) in Korea: Bold risks on the national foundation. In J. Enever, J. Moon \& U. Raman (Eds.), Young Learner English Language Policy and Implementation: International Perspectives (pp. 95-102). Reading: Garnet Education.

Li, D.F. . (1998). 'It's always more difficult than you plan and imagine': Teachers' perceived difficulties in introducing the communicative approach in South Korea. TESOL Quarterly, 32(4), 677-703.

Liddicoat, A.J. (2004). Language Policy and Methodology. International Journal of English Studies, 4(1), 153-171.

Littlewood, W. (2007). Communicative and task-based language teaching in East Asian classrooms. Language Teaching, 40, 243-249.

Littlewood, W., \& Yu, B. (2011). First language and target language in the foreign language classroom. Language Teaching, 44(1), 64-77.

McKay, S. (2003). Teaching English as an internatonal language: the Chilean context. ELT Journal, 57(2), 139-148.

Mee, C. Y. (2003). English Language Teaching in Singapore today. In W. K. Ho \& R. Y. L. Wong (Eds.), English Language Teaching in East Asia Today: Changing Policies and Practices (pp. 351-374). Singapore: Eastern Universities Press.

MEST. (2008). Major Policies and Plans for 2009.

MEST. (2009). Major Policies and Plans for 2010.

MEST. (2010). Major Policies and Plans for 2011. Retrieved from http://www.mest.go.kr. 
Mitchell, R., \& Lee, J.H.-W. (2003). Sameness and difference in classroom learning cultures: interpretations of communicative pedagogy in the UK and Korea. Language Teaching Research, 7(1), 35-63.

Nguyen, H.T.M. (2011). Primary English language education policy in Vietnam: insights from implementation. Current Issues in Language Planning, 12(2), 225249.

Nikolov, M. (2009b). The dream and the reality of early programmes in Hungary. In J. Enever, J. Moon \& U. Raman (Eds.), Young Learner English Language Policy and Implementation: International Perspectives (pp. 121-129). Reading: Garnet Education.

Nikolov, M., \& Mihaljevic Djigunovic, J. (2006). Recent research on age, second language aquisition, and early foreign language learning. Annual Review of Applied Linguistics, 26, 234-260.

Nunan, D. (2003). The impact of English as a global language on educational policies and practices in the Asia-Pacific region. TESOL Quarterly, 37(4), 589-613.

Nur, C. (2003). English Language Teaching in Indonesia: changing policies and practical constraints. In W. K. Ho \& R. Y. L. Wong (Eds.), English Language Teaching in East Asia Today: Changing Policies and Practices (pp. 163-172). Singapore: Eastern Universities Press.

Oppenheim, A.N. . (1992). Questionnaire design: Interviewing and attitude measurement. London: Continuum. .

Pandian, A. (2003). English Language Teaching in Malaysia today. In W. K. Ho \& R. Y. L. Wong (Eds.), English Language Teaching in East Asia Today: Changing Policies and Practices (pp. 269-292). Singapore: Eastern Universities Press.

Piller, I., \& Cho, J. (2013). Neoliberalism as language policy. Language in Society, 42, 23-44.

Pinter, A. (2006). Teaching Young Language Learners. Oxford: Oxford University Press.

Prapaisit de Segovia, L., \& Hardison, D. M. (2008). Implementing education reform: EFL teachers' perspectives. ELT Journal, 63(2), 154-162.

Ricento, T., \& Hornberger, N.H. (1996). Unpeeling the onion: language planning and policy and the ELT professional. TESOL Quarterly, 30(3), 401-427.

Shim, R. J., \& Baik, M. J. (2003). English Education in South Korea. In W. K. Ho \& R. Y. L. Wong (Eds.), English Language Teaching in East Asia Today: Changing Policies and Practices (pp. 235-256). Singapore: Eastern Universities Press.

van Lier, L. (1988). The Classroom and the Language Learner. London: Longman.

Watson-Gegeo, K. A. (1988). Ethnography in ESL: defining the essentials. TESOL Quarterly, 22(4), 575-592.

Wedgwood, R. (2007). Education and poverty reduction in Tanzania. International Journal of Educational Development, 27, 383-396.

Xinmin, Z., \& Adamson, B. (2003). The pedagogy of a secondary school teacher of English in the People's Republic of China: Challenging the stereotypes. RELC Journal, 34(3), 323-337.

Figure 1 - Level of education of survey respondents 


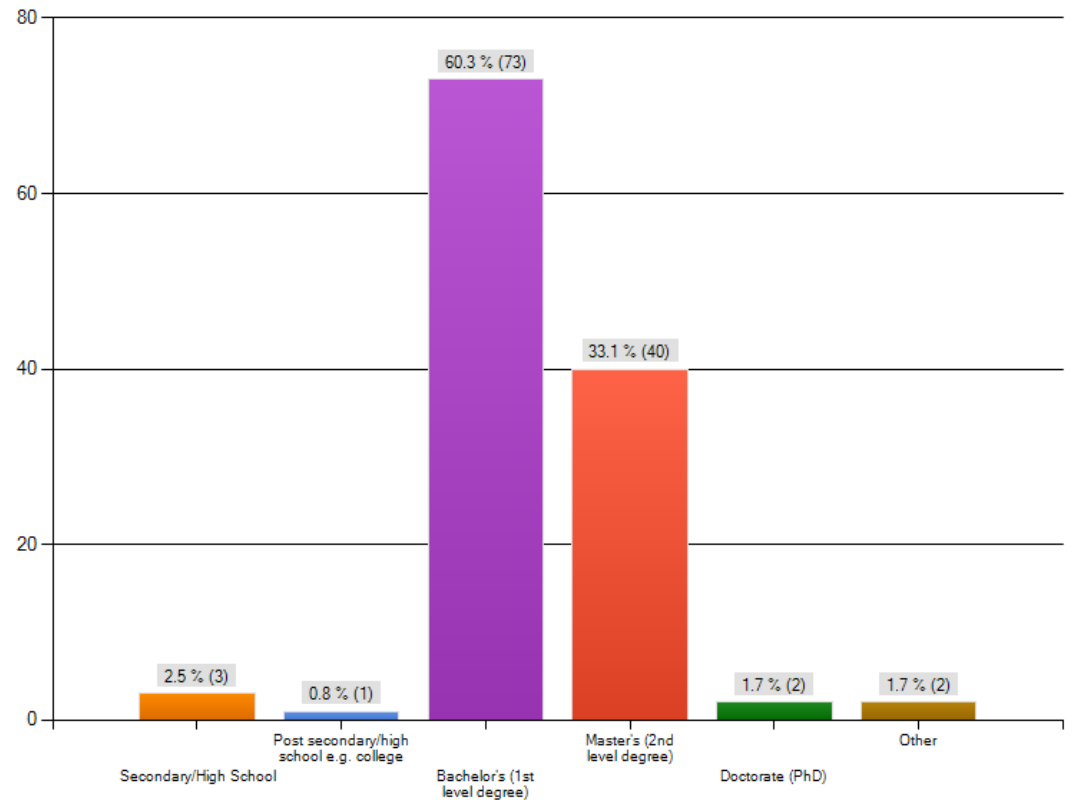

Figure 2 Age of survey respondents

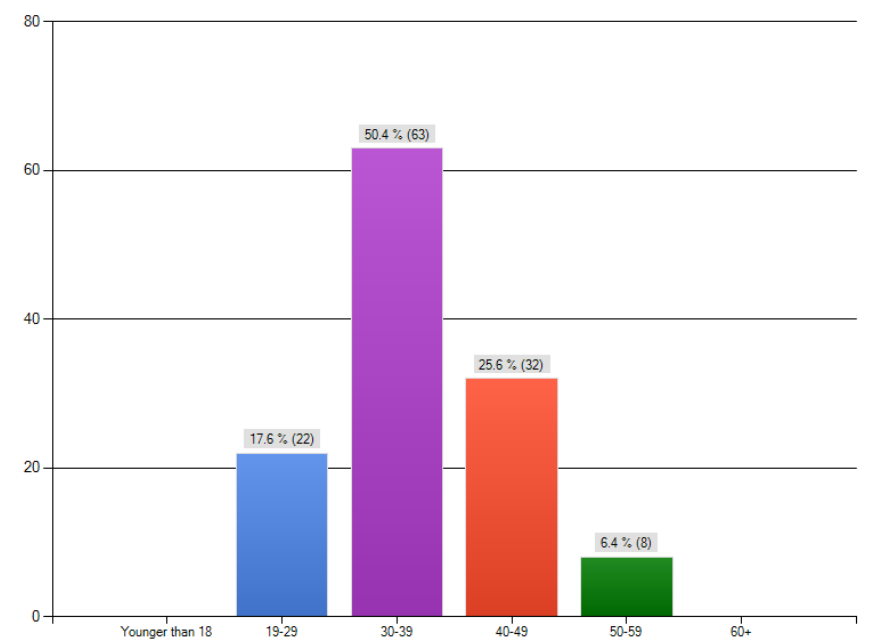

Figure 3 - number of years as a primary school teacher of English 


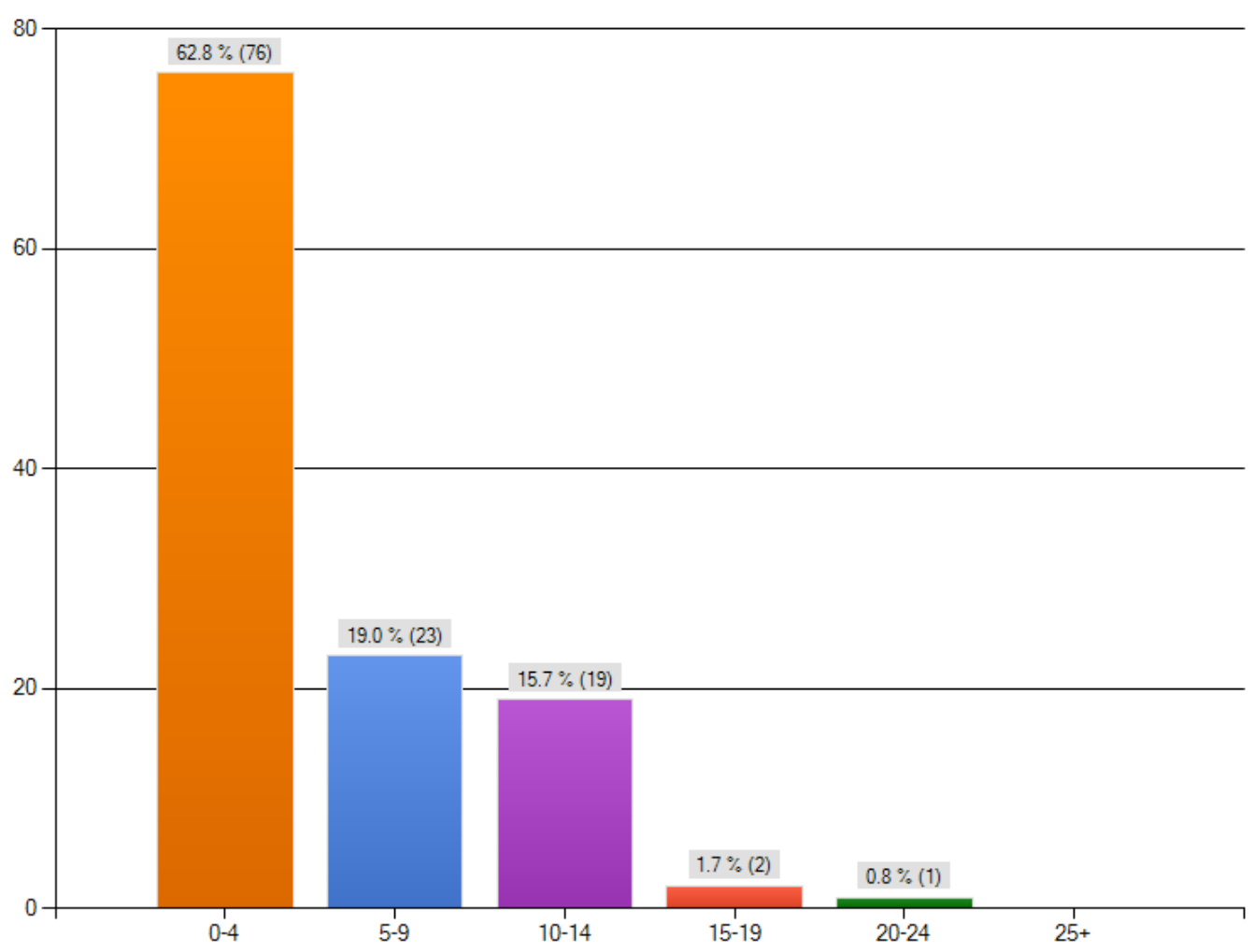

Table 1: Frequency of use of activities

\begin{tabular}{|l|l|l|l|}
\hline Activities used every lesson or often & & Activities used rarely or never & \\
\hline Playing games & $91.9 \%$ & Reading silently & $65.9 \%$ \\
\hline Children repeating after the teacher & $87.2 \%$ & Translation exercises & $60.0 \%$ \\
\hline Listening to tape-recorder/CD & $81.2 \%$ & Creative writing & $56.8 \%$ \\
\hline Songs & $76.6 \%$ & Grammar explanations & $51.9 \%$ \\
\hline Watching videos/TV & $61.0 \%$ & Rhymes and/or poems & $50.1 \%$ \\
\hline Children reading out loud & $56.1 \%$ & & \\
\hline Role-play & $50.0 \%$ & & \\
\hline
\end{tabular}

i See http://www.talk.go.kr/ 
iicoursebooks are often published with an accompanying teacher's book with suggestions for activities and a student's workbook with further exercises

iii I would like to thank one of the survey teachers for this observation.

ivhttp://english.moe.go.kr/web/40444/site/contents/en/en 0275.jsp [accessed 20/06/2013] 